\title{
Occurrence and spatial-temporal distribution of herbicide residues in the Ipojuca River sub-basin, Pernambuco, Brazil
}

\author{
Adson da S. G. Ferreira ${ }^{1}$, Henrique C. M. P. da Silva ${ }^{1}$, Hélio O. S. Rodrigues ${ }^{1}$, \\ Marileide Silva² \& Eden C. de Albuquerque Junior ${ }^{1}$ \\ ${ }^{1}$ Associação Instituto de Tecnologia de Pernambuco/Programa de Pós-graduação em Tecnologia Ambiental. Recife, PE. E-mail: adsonfederal@gmail.com \\ (Corresponding author); mestrado@itep.br; helio.hos@gmail.com; eden@itep.br \\ ${ }^{2}$ Associação Instituto de Tecnologia de Pernambuco. Recife, PE. E-mail: marileide@itep.br
}

Key words:

sugarcane

pesticides

environmental contamination

LC-MS/MS

\begin{abstract}
A B S T R A C T
The intensive use of pesticides to control pests in agriculture has exposed the environment and humans to a variety of risks. Among the crops with higher consumption of these compounds there is the sugarcane, developed in regions bordered by large watersheds. In this work, the occurrence of pesticides in the water of Ipojuca River was investigated in a $50 \mathrm{~km}$ range of its eastern portion, in a region noted for intense agroindustrial activity, especially by sugarcane cultivation, in the state of Pernambuco. Among fungicides, herbicides, insecticides and carbamates, 238 pesticides were investigated in the Ipojuca River using the technique of liquid chromatography coupled to tandem mass spectrometry (LC-MS/MS). The study, conducted in the months of May, June, October and November 2012, detected the presence of Diuron and Ametryn herbicide residues in $100 \%$ of the water samples at concentrations from 0.01 to $1.4 \mu \mathrm{g} \mathrm{L}^{-1}$. The detection of these herbicides, even at residual concentrations, can lead to perceptible ecological changes in the long term, such as the reduction of the biological potential of animal and plant species.
\end{abstract}

\section{Palavras-chave:}

cana-de-açúcar

pesticidas

contaminação ambiental

LC-MS/MS

\section{Ocorrência e distribuição espaço-temporal de resíduos de herbicidas na sub-bacia do Rio Ipojuca, Pernambuco, Brasil}

\section{R E S U M O}

O uso intensivo de pesticidas no controle de pragas na agricultura tem exposto o meio ambiente e o homem a diferenciados riscos. Entre as culturas que apresentam maior consumo desses compostos se encontra a da cana-de-açúcar, desenvolvida em regiões margeadas por grandes bacias hidrográficas. Em uma faixa de $50 \mathrm{~km}$ investigou-se, neste trabalho, a ocorrência de pesticidas nas águas do Rio Ipojuca, na sua porção Leste, em uma região que se destaca pela intensa atividade agroindustrial, sobretudo sucroalcooleira, no estado de Pernambuco. Dentre fungicidas, herbicidas, inseticidas e carbamatos, 238 pesticidas foram investigados nas águas do Rio Ipojuca utilizando-se a técnica de cromatografia líquida acoplada à espectrometria de massas em tandem (LC-MS/MS). O estudo realizado nos meses de maio, junho, outubro e novembro de 2012, detectou a presença de resíduos dos herbicidas Ametrina e Diuron em 100\% das amostras de água, em concentrações que variaram de 0,01 a $1,4 \mu \mathrm{g} \mathrm{L}^{-1}$. A detecção desses herbicidas, mesmo que em concentrações residuais, pode levar a alterações ecológicas perceptíveis a longo prazo, como a diminuição do potencial biológico de espécies animais e vegetais. 


\section{INTRODUCTION}

Among the pesticides used worldwide, those in the class of herbicides are the most consumed, followed by insecticides, fungicides and acaridcies (Jardim \& Andrade, 2009). Ferreira et al. (2014) claim that in Brazil only the class of herbicides moved, in 2013 , US $\$ 3.74$ billions and $12.9 \%$ of the sales are destined to sugarcane.

Sugarcane occupies large areas in Brazil, consolidating as a crop with high application of herbicides, intensifying the contamination of surface and subsurface waters. This scenario has required studies on the behavior of these products in the environment (Masters et al., 2013; Dellamatrice \& Monteiro, 2014; Lorente et al., 2015).

According to Arias et al. (2007), herbicides can be dispersed in the environment through various mechanisms, such as runoff, leaching, volatilization and drift, thus reaching water bodies directly, through rainwater or irrigation water, or indirectly, through percolation in the soil, reaching the water table.

The intensification in the use of water from the Ipojuca River and the impact caused by sugarcane cultivation, real estate speculation and unorganized use and occupation of the soil along its watershed have been a constant focus of studies (Gunkel et al., 2007; Gonçalves et al., 2012; Souza-Santos \& Araújo, 2013).

This study aimed to investigate the occurrence of pesticides in the eastern portion of the Ipojuca River basin, in Pernambuco, since the diagnosis of use of these compounds in sugarcane cultivation is a primordial tool for an adequate management of agricultural activities, also serving as support for the processes of evaluation of the environmental quality of the water from the Ipojuca River.

\section{Material ANd Methods}

The Ipojuca River, the main river of the Ipojuca River Basin, rises in the Serra do Pau D'Arco in the municipality of Arcoverde ( $08^{\circ} 25^{\prime} 15^{\prime \prime} \mathrm{S}$; $\left.37^{\circ} 03^{\prime} 41^{\prime \prime} \mathrm{W}\right), 244 \mathrm{~km}$ away from the Pernambuco capital, and flows into the Atlantic Ocean, on the south coast of the state. The Ipojuca River covers two phytogeographic regions, being temporary in the Agreste region and perennial in the 'Zona da Mata' (SRH, 2010).

According to Nimer (1979), the climate in the eastern portion of the Ipojuca River Basin is hot and humid, pseudotropical, As', according to Köppen's classification. The mean annual temperature is $24^{\circ} \mathrm{C}$ and the annual rainfall regime varies from 1,850 to $2,364 \mathrm{~mm}$.
The Ipojuca River sub-basin, in its eastern portion, has been widely used by agriculture, industry and supply. Approximately $652,000 \mathrm{~km}^{2}$ of this sub-basin are used for sugarcane cultivation. This region is considered as the second largest producer of sugarcane in Pernambuco (Gunkel et al., 2007).

Eight points distributed along $50 \mathrm{~km}$ of the Ipojuca River, all georeferenced with a GPS (Global Position System) receiver unit, adjusted to the Geographic Coordinate System Datum WGS84 (Table 1), were selected through a simple random sampling to evaluate the occurrence of pesticides (Figure 1).

The collection of water samples were performed from May to June (rainy months) and from October to November (dry months) in 2012, in periods of low tide, during the apices of new and full moon, when the interference of the continental water on the estuary is greater.

Sampled in each point using a Van Dorn bottle, $4 \mathrm{~L}$ of water were transferred to amber glass flasks, placed in the ice and immediately taken to the Laboratory of Agrochemicals of the Institute of Technology of Pernambuco for the analysis of pesticide residues. The procedures of sampling, collection and storage followed the recommendations of the Manual of Procedures of Sample Collections in Agricultural Areas for Analysis of Environmental Quality, of the Brazilian Agricultural Research Corporation - EMBRAPA (Filizola et al., 2006).

The determination of pesticides in the water of the Ipojuca River consisted in the extraction in solid phase, with C18 disks, combined with the LC-MS/MS technique, a method adopted by the United States Environmental Protection Agency (EPA, 2012), with modifications of the procedure by the laboratory to adjust to the previously mentioned technique.

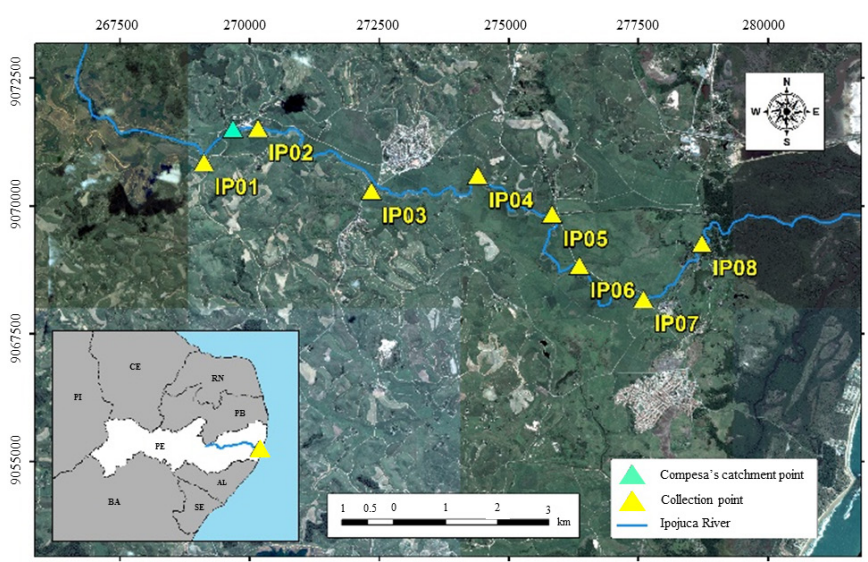

Figure 1. Map of location of the water collection stations along the Ipojuca River, PE

Table 1. Location of the water collection stations along Ipojuca River

\begin{tabular}{cccl}
$\begin{array}{c}\text { Collection } \\
\text { stations }\end{array}$ & $\begin{array}{c}\text { Geographic coordinates } \\
\text { (UTM }-25 S)\end{array}$ & \multicolumn{1}{c}{ Reference } \\
IP01 & $2269123.41 \mathrm{E}$ & $9070859.90 \mathrm{~N}$ & Close to the pipelins/Sugarcane (Saccharum L.) plantation \\
IP02 & $270164.80 \mathrm{E}$ & $9071524.81 \mathrm{~N}$ & $\begin{array}{l}\text { Close to the Ipojuca Mill/ Sugarcane plantation/close to the water catchment point of the Compesa } \\
\text { (Sanitation Company of Pernambuco) }\end{array}$ \\
IP03 & $272353.40 \mathrm{E}$ & $9070296.45 \mathrm{~N}$ & Under the viaduct of the BR-101 South Highway, close to the urban zone of the city of Ipojuca -PE \\
IP04 & $274408.30 \mathrm{E}$ & $9070598.20 \mathrm{~N}$ & Plantation of sugarcane and cassava (Manihot utilissima) \\
IP05 & $275840.45 \mathrm{E}$ & $9069841.24 \mathrm{~N}$ & Island of mud/Sugarcane plantation \\
IP06 & $276365.24 \mathrm{E}$ & $9068835.26 \mathrm{~N}$ & Plantation of bamboo (Phyllostachys castillonis) and sugarcane \\
IP07 & $277602.69 \mathrm{E}$ & $9068183.64 \mathrm{~N}$ & Old iron bridge/constructions \\
IP08 & $278730.40 \mathrm{E}$ & $9069270.20 \mathrm{~N}$ & Small vilage/close to the mangrove \\
\hline
\end{tabular}


Among herbicides (68), fungicides (73), pyrethroids (18), insecticides (63) and carbamates (16), 238 pesticides were analyzed, all from the brand Dr. Ehrenstorfer $\mathrm{GmbH}$ (Augsburg, Alemanha). For the analysis, only the main products were considered, disregarding metabolytes or secondary products of degradation of the pesticides.

The identification and quantification of the levels of pesticides were performed using a LC-MS/MS system (Waters, series Allience HTe Quattro Premier), Alltima C18 Column $(5 \mu \mathrm{m}, 150 \times 3.2 \mathrm{~mm})$, mobile phase composed of ammonium formate $\left(5 \mathrm{mmol} \mathrm{L}^{-1}\right)$ (phase A) and methanol (phase B). The injected volume of sample was $5 \mu \mathrm{L}$.

The conditions of the mass detector were: source (ES+), capillary voltage $(1.00 \mathrm{kV})$, cone voltage depending on the analyte, source temperature $\left(110^{\circ} \mathrm{C}\right)$, cone gas flow $\left(50 \mathrm{~L} \mathrm{~h}^{-1}\right)$ of nitrogen and gas of desolvation $\left(800 \mathrm{~L} \mathrm{~h}^{-1}\right)$, desolvation temperature $\left(400^{\circ} \mathrm{C}\right)$, collision gas pressure $(\mathrm{Ar})\left(+3.50 \times 10^{-3}\right.$ $\mathrm{mBar})$ and photomultiplier $(650 \mathrm{~V})$.

Free from pesticides, $500 \mathrm{~mL}$ of raw water were contaminated with a mixture-solution of the 238 compounds analyzed by the laboratory at a mean concentration of 0.01 and $0.5 \mu \mathrm{g} \mathrm{L}^{-1}$. These samples were used to evaluate the efficiency of the method through recovery experiments (accuracy and precision).

The limits of detection (LOD) and quantification (LOQ) of the method were estimated using mixed solutions of standards of pesticides, with concentrations of $0.01 \mu \mathrm{g} \mathrm{mL}^{-1}$ for the LC/ MS-MS system. The solutions were prepared through the technique of successive dilutions using stock solutions at $0.1 \mathrm{mg} \mathrm{L}^{-1}$, of the individual pesticides, in LC/MS methanol (CHROMASOLV, FLUKA).

The LOD and LOQ of the method were estimated at 95\% of confidence based on the parameters of the analytical curve, obtained through linear regression of the results of three injections of each concentration using Eqs. 1 and 2.

$$
\begin{aligned}
& \mathrm{LOD}=3.3 \frac{\mathrm{s}}{\mathrm{S}} \\
& \mathrm{LOQ}=10 \frac{\mathrm{s}}{\mathrm{S}}
\end{aligned}
$$

where:

$s \quad$ - estimate of the standard deviation of the regression line equation; and,

S - slope or angular coefficient of the analytical curve.

Considering a probability level of 0.05 , an analysis of variance (ANOVA - single factor) was applied to test the hypothesis of influence of seasonality on the levels of pesticides. In addition, a descriptive statistical analysis was performed in the data, using Box plot graphs, calculating mean, standard error, standard deviation, minimum, maximum and outliers. In both cases, the statistical program Statistica ${ }^{\circ}$ was used.

\section{Results AND Discussion}

The method for the determination of pesticides showed LOD of $0.008 \mu \mathrm{g} \mathrm{L}^{-1}$ and LOQ of $0.01 \mu \mathrm{g} \mathrm{L}^{-1}$. The accuracy of the method for the 238 analyzed compounds was estimated to be between 70.6 and $119.2 \%$ and precision between 1.1 and $18.6 \%$. These values meet the range of acceptability for recovery (70 and $120 \%)$ and precision $(<20 \%)$, according to Pihlström (2012).

Considering a tolerable sampling error of 0.05 , Diuron and Ametryn were detected in all water samples collected in the Ipojuca River along the investigated perimeter. This result is corrborated by other studies conducted in watershed regions in Brazil and worldwide, bordered by large sugarcane cultivation areas where these herbicides were found (Echeverría-Sáenz et al., 2012; Hermosin et al., 2013).

Diuron and Ametryn are herbicides that have pre- and post-emergence action and are found among various options of photosystem II-inhibiting herbicides, registered for the sugarcane crop (Rodrigues \& Almeida, 2005). According to Procópio et al. (2004), these herbicides are recommended for the control of grasses and broad and evergreen leaves of hard control.

The levels of the herbicides found in the present study do not follow a seasonal pattern of occurrence, although the highest concentrations of Diuron are more present in the rainiest months, May to August (Figure 2).

Despite the lack of a defined seasonal variation $(F=1.28$; $p=0.30$ ), the levels of Diuron varied on average by $0.20 \pm$ $0.37 \mu \mathrm{g} \mathrm{L}^{-1}$ (May-June/2012) and by $0.03 \mathrm{mg} \mathrm{L}^{-1}$ (NovemberDecember/2012), evidencing significantly higher values of this herbicide during the rainy period, in comparison to the dry period in the region (Figure $3 \mathrm{~A}$ ).

The same observation was found regarding the influence of seasonality on the detected levels of Ametryn ( $F=1.93$; p $=0.15$ ), evidencing significantly close values during the rainy and dry periods $(\mathrm{F}=1.93 ; \mathrm{p}=0.15)$ (Figure $3 \mathrm{~B}$ ).

Unlike the levels of Ametryn found in the water of the Ipojuca River, the levels of Diuron varied considerably during the month of May $(\mathrm{CV} \%=160.4 \%)$, compared with the subsequent months, which showed variations of $121.8,34.5$ and $55.6 \%$, respectively. The highest levels of Diuron were observed in the area where the collection points IP04, IP05, IP06 and IP07 are located.

Besides the rainfall and pedology of the region, the presence of shallow and sandy soils and accentuated slope can also intensify

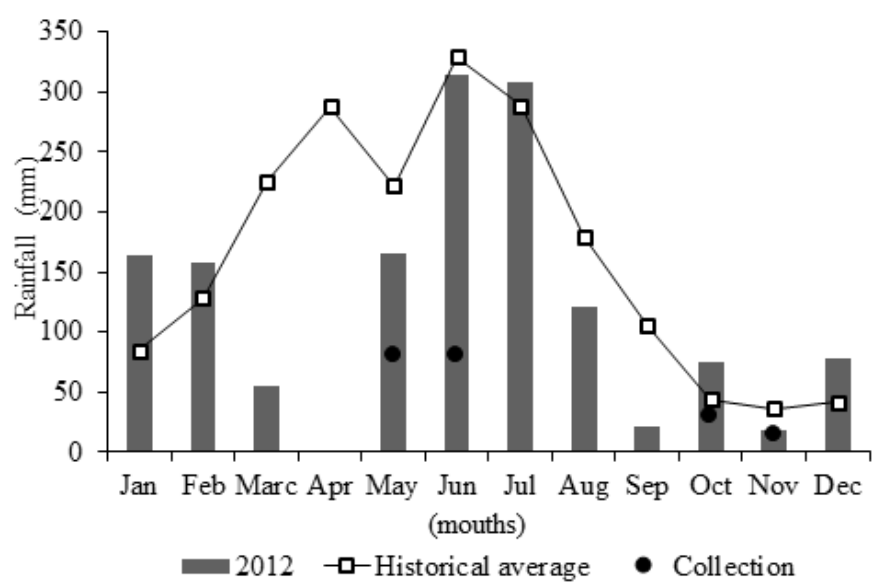

Figure 2. Rainfall in the studied area (monthly accumulation in 2012 and historical average of the last 10 years) 

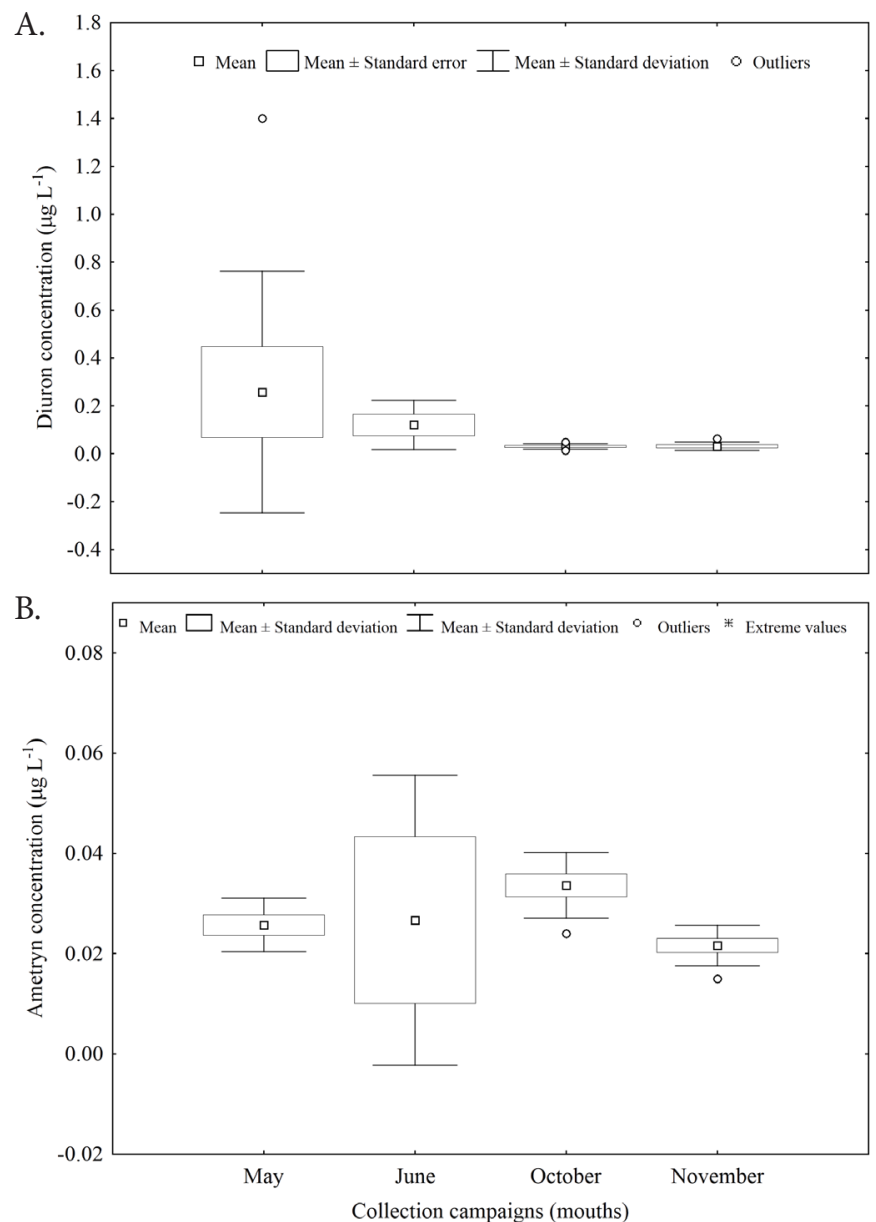

Figure 3. Variation of the concentrations of Diuron $(A)$ and Ametryn (B) in the water of the Ipojuca River, PE, between May and November 2012

the dynamics of these herbicides from terrestrial to aquatic systems, according to Spongberg \& Martin-Hayden (1997).

Blanco et al. (2010) defend that the concentration of herbicides in the environment may vary according to their application during the period of sugarcane cultivation. Thus, associated with environmental factors, the period of application of herbicides in the sugarcane crop in the 'Zona da Mata' South of Pernambuco, which extends from January to October, may also have influenced the detected levels of herbicides.

According to Figure $3 \mathrm{~A}$ and 3B, the occurrence of Diuron and Ametryn in the water of the Ipojuca River was more evident in the first months of sugarcane cultivation, pre- and post-emergence periods, when weed control is more intensive.

The environmental effects caused by these herbicides are mainly related to their physico-chemical properties. The persistency, in turn, results from the exiguity of processes that alter the chemical structure of these compounds and promote their dispersion, and is dependent on physical, chemical and biological processes that occur in the environment.

Therefore, the physico-chemical properties of Diuron and Ametryn are determinant in the processes of adsorption, leaching and microbial and chemical decomposition that occur in the soil, affecting the persistency of these herbicides in the soil and favoring their occurrence in the aquatic systems (Table 2).

Regarding these properties, Diuron belongs to the chemical group of the substituted ureas, has wide spectrum of action and high persistency (one to twelve months), and can be found in the sediment of in the water column (Giacomazzi \& Cochet, 2004). According to Cabrera et al. (2010), this herbicide is a non-ionic compound and, as observed in Table 2, has moderate solubility in water.

Ametryn, in turn, belongs to the group of the triazines. According to Roberts et al. (1998) and Briceño et al. (2007), it is a ionizable herbicide, with basic character, and stable in neutral medium, which provides it with high environmental persistency.

Because of these reasons, the physico-chemical properties of these herbicides provide these compounds with mobility and persistency in water and in the soil. Consequently, their residues were found along all the collection points, from IP01 to IP08.

Similar results were reported by Britto et al. (2012), who observed the presence of Diuron and Ametryn in the water from the Poxim River, Sergipe, at levels that varied from 0.03 to 0.9 and 0.03 to $0.5 \mu \mathrm{g} \mathrm{L}-1$, respectively. Muendo et al. (2012) also investigated the presence of herbicides in areas of sugarcane cultivation bordered by the Kuywa River, in Kenya, and observed Diuron levels varying from 0.44 to $1.75 \mu \mathrm{g} \mathrm{L}^{-1}$. In both studies, the rainy period influenced the detected levels of herbicides.

The detection of Diuron and Ametryn in the water of the Ipojuca River in all points (IP01-IP08), is worrying because their chronical effects through contamination, even at residual concentrations (sublethal), may originate perceptible alterations in the long term, such as the decrease in the biological potential of animal and plant species, as reported by Bell \& Duke (2005) and Pereira et al. (2015).

\section{Conclusions}

1. The presence of Diuron ( 0.01 to $\left.1.4 \mu \mathrm{g} \mathrm{L}^{-1}\right)$ and Ametryn ( 0.01 to $0.06 \mu \mathrm{g} \mathrm{L}^{-1}$ ) was detected in the surface waters of the Ipojuca River, in its eastern portion, in all collection points (IP01-IP08) at levels that varied in time and space.

2. The levels of the herbicides Ametryn and Diuron were not influenced by the rainy period; however, other environmental factors may have collaborated to the variation in the levels of Diuron, unlike the levels of Ametryn, which were significantly close during the rainy and dry periods.

3. The residual detection of the herbicides Diuron and Ametryn in the waters of the Ipojuca River in all points is worrying, because their chronical effects through contamination, even at low concentrations, may originate perceptible alterations in the long term.

Table 2. Environmentally relevant chemical properties of Diuron and Ametryn

\begin{tabular}{|c|c|c|c|c|c|}
\hline $\begin{array}{c}\text { Chemical group } \\
\text { (active ingredient) }\end{array}$ & Target weed & Mode of action & $\begin{array}{l}\text { Solubility in water } \\
\left(\mathrm{mg} \mathrm{L}^{-1}\right)\end{array}$ & $\begin{array}{l}\text { Half-life in the soil } \\
\text { (DT }_{50}: \text { days) }\end{array}$ & $\begin{array}{l}\text { Constant of adsorption } \\
\text { to organic carbon (koc) }\end{array}$ \\
\hline Ametryn & \multirow{2}{*}{ Grass } & \multirow{2}{*}{ Inhibition of photosystem II } & 35.6 & 75 & 1067 \\
\hline Diuron & & & 200 & 37 & 316 \\
\hline
\end{tabular}




\section{Literature Cited}

Arias, A. R. L.; Buss, D. F.; Alburquerque, C.; Inácio, A. F.; Freire, M. M.; Egler, M.; Mugnai, R.; Baptista, D. F. Utilização de bioindicadores na avaliação de impacto e no monitoramento da contaminação de rios e córregos por agrotóxicos. Ciência Saúde Coletiva, v.12, p.6172, 2007. http://dx.doi.org/10.1590/S1413-81232007000100011

Bell, A. M.; Duke, N. C. Effects of photosystem II inhibiting herbicides on mangroves-preliminary toxicology trials. Marine Pollution Bulletin, v.51, p.297-307, 2005. http://dx.doi.org/10.1016/j. marpolbul.2004.10.051

Blanco, F. M. G.; Velini, E. D.; Batista Filho, A. Persistência do herbicida sulfentrazone em solo cultivado com cana-de-açúcar. Bragantia, v.69, p.71-75, 2010. http://dx.doi.org/10.1590/S000687052010000100010.

Briceño, G.; Palma, G.; Duran, N. Influence of organic amendment on the biodegradation and movement of pesticides. Critical Reviews in Environmental Science and Technology, v.37, p.233-271, 2007. http://dx.doi.org/10.1080/10643380600987406.

Britto, F. B.; Vasco, A. N.; Pereira, A. P. S.; Méllo Júnior, A. V.; Nogueira, L. C. Herbicidas no alto Rio Poxim, Sergipe e os riscos de contaminação dos recursos hídricos. Revista Ciência Agronômica, v.43, p.390-398, 2012. http://dx.doi.org/10.1590/S1806-66902012000200024.

Cabrera, L. C.; Caldas, S. S.; Rodrigues, S.; Bianchini, A.; Duarte, F. A.; Primel, E. G. Degradation of herbicide diuron in water employing the $\mathrm{Fe}^{0} / \mathrm{H}_{2} \mathrm{O}_{2}$ system. Journal of the Brazilian Chemical Society, v.21, p.2347-2352, 2010. http://dx.doi.org/10.1590/S010350532010001200023

Dellamatrice, P. M.; Monteiro, R. T. R. Principais aspectos da poluição de rios brasileiros por pesticidas. Revista Brasileira de Engenharia Agrícola e Ambiental, v.18, p.1296-1301, 2014. http://dx.doi. org/10.1590/1807-1929/agriambi.v18n12p1296-1301.

Echeverría-Sáenz, S.; Mena, F.; Pinnock, M.; Ruepert, C.; Solano, K.; De la Cruz, E.; Campos, B.; Sánchez-Avila, J.; Lacorte, S.; Barata, C. Environmental hazards of pesticides from pineapple crop production in the Río Jiménez watershed (Caribbean Coast, Costa Rica). Science of the Total Environment, v.440, p.106-114, 2012. http://dx.doi.org/10.1016/j.scitotenv.2012.07.092.

EPA - Agência de Proteção Ambiental dos Estados Unidos. Method 525.2: Determination of organic compounds in drinking water by liquid-solid extraction and capillary column gas chromatography/ mass spectrometry. Ohio: EPA, 2012. 60p.

Ferreira, C. R. R. P. T.; Vegro, C. L. R.; Camargo, M. L. B. Defensivos agrícolas: Comercialização recorde em 2013 e expectativas de acréscimo nas vendas em 2014. Análises e Indicadores do Agronegócio, v.9, p.1-5, 2014.

Filizola, H. F.; Gomes, M. A. F.; Souza, M. D. Manual de procedimentos de coleta de amostras em áreas agrícolas para análise da qualidade ambiental: Solo, água e sedimentos. Jaguariúna: Embrapa Meio Ambiente. 1.ed., 2006. 169p.

Giacomazzi, S.; Cochet, N. Environmental impact of diuron transformation: A review. Chemosphere, v.56, p.1021-1032, 2004. http://dx.doi.org/doi:10.1016/j.chemosphere.2004.04.061.

Gonçalves, G. M. S.; Gurgel, I. G. D.; Costa, A. M.; Almeida, L. R.; Lima, T. F. P.; Silva, E. Uso de pesticidas e a relação com a saúde na etnia Xukuru do Ororubá, Pernambuco, Brasil. Saúde e Sociedade, v.21, p.1001-1012, 2012.http://dx.doi.org/10.1590/ S0104-12902012000400017.
Gunkel, G.; Kosmol, J.; Sobral, M. C. M.; Rohn, H.; Montenegro, S. M. G. L.; Aureliano, J. T. Sugar cane industry as a source of water pollution - Case study on the situation in Ipojuca river, Pernambuco, Brazil. Water, Air, \& Soil Pollution, v.180, p.261-269, 2007. http://dx.doi.org/10.1007/s11270-006-9268-X.

Hermosin, M. C.; Calderon, M. J.; Real, M.; Cornejo, J. Impact of herbicides used in olive groves on waters of the Guadalquivir river basin (Southern Spain). Agriculture, Ecosystems \& Environment, v.164, p.229-243, 2013. http://dx.doi.org/10.1016/j.agee.2012.09.021.

Jardim, I. C. S. F.; Andrade, J. A. Resíduos de pesticidas em alimentos: Uma preocupação ambiental global - Um enfoque às maçãs. Química Nova, v.32, p.996-1012, 2009. http://dx.doi.org/10.1590/ S0100-40422009000400031

Lorente, C.; Causapé, J.; Glud, R. N.; Hancke, K.; Merchán, D.; Muñiz, S.; Val, J.; Navarro, E. Impacts of agricultural irrigation on nearby freshwater ecosystems: The seasonal influence of triazine herbicides in benthic algal. Science of The Total Environment, v.503-504, p.151-158, 2015. http://dx.doi.org/10.1016/j.scitotenv.2014.06.108.

Masters, B.; Rohde, K.; Gurner, N.; Reid, D. Reducing the risk of herbicide runoff in sugarcane farming through controlled traffic and early-banded application. Agriculture, Ecosystems and Environment, v.180, p.29-39, 2013. http://dx.doi.org/ 10.1016/j. agee.2012.02.001

Muendo, B. M.; Lalah, J. O.; Getenga, Z. M. Behavior of pesticide residues in agricultural soil and adjacent River Kuywa sediment and water samples from Nzoia sugarcane belt in Kenya. Environmentalist, v.32, p.433-444, 2012. http://dx.doiorg/10.1007/ s10669-012-9407-4

Nimer, E. Pluviometria e recursos hídricos dos Estados de Pernambuco e Paraíba. Rio de Janeiro: IBGE/Recursos Naturais e Meio Ambiente, v.3, 1979. 128p.

Pereira, T. S. B.; Boscolo, C. N. P.; Silva, D. G. H.; Batlouni, S. R.; Schlenk, D.; Almeida, E. A. Anti-androgenic activities of diuron and its metabolites in male Nile tilapia (Oreochromis niloticus). Aquatic Toxicology, v.164, p.10-15, 2015. http://dx.doi. org/10.1016/j.aquatox.2015.04.013.

Pihlström, T. Method validation and quality control procedures for pesticide residues analysis in food and feed. Document n. SANCO/12495/2011. Uppsala: Pihlström National Food Administration. 2012. 41p.

Procópio, S. O.; Silva, A. A.; Vargas, L. Manejo e controle de plantas daninhas em cana-de-açúcar. In: Vargas, L.; Roman, E. S. (ed.) Manual de manejo e controle de plantas daninhas. Bento Gonçalves: Embrapa Uva e Vinho, 2004. p.397-452.

Roberts, T. R.; Hutson, D. H.; Lee, P. W.; Nicholls, P. H.; Plimmer, J. R.; Roberts, M. C.; Croucher, L. Metabolic pathways of agrochemicals: Herbicides and plant growth regulators. London: The Royal Society of Chemistry, 1998. 849p.

Rodrigues, B. N.; Almeida, F. S. Guia de herbicidas. Londrina: IAPAR, 2005. 592p.

Souza-Santos, L. P.; Araújo, R. J. Water toxicity assessment in the Suape estuarine complex (PE-Brazil). Ecotoxicology and Environmental Contamination, v.8, p.59-65, 2013. http://dx.doi.org/10.5132/ eec.2013.01.009.

Spongberg, A.; Martin-Hayden, J. M. Pesticide stratification in an engineered wetland delta. Environmental Science and Technology, v.31, p.3161-3165, 1997. http://dx.doi.org/10.1021/es970144m.

SRH - Secretaria de Recursos Hídricos. Plano hidroambiental da bacia hidrográfica do Rio Ipojuca: Diagnóstico hidroambiental. Pernambuco: SRH. v.01/03, 2010. 344p. 